\title{
Recent Developments In Selected Asian Countries' Bankruptcy Laws: Should Multinational Company Strategists Be Concerned?
}

Jane LeMaster, (E-mail: jlemaster@utpa.edu), University of Texas Pan American Clara Downey, (E-mail: claradowney@gmail.com), University of Texas Pan American F.J. Brewerton, (E-mail: brewerton@utpa.edu), University of Texas Pan American

\begin{abstract}
This paper explains why multinational companies should be concerned about adjudication of international insolvencies. The Territorialism and Universalism Models of bankruptcy law are reviewed and employed as a backdrop to describe recent developments in the insolvency laws of four Asian nations. We conclude with an assessment of the status of the selected Asian nations' insolvency laws, progress toward a uniform global system for resolving multinational insolvencies, and the strategic implications these developments hold for strategy formulation.
\end{abstract}

\section{INTRODUCTION}

lobalization of both markets and the production function requires multinational corporations to consider the global economy as a single market. This paradigm shift has created dramatic changes in the fundamental way international business is conducted. For example, by the end of the twentieth century, the U.S. share of world output had decreased by $50 \%$, along with its contribution of worldwide foreign direct investment (FDI) decreasing by approximately 67\% (Hill, 2001). In comparison, Western European and Southeast Asian economies were increasing their share of world output, while a large number of Japanese and European multinationals emerged. Globalizing markets and production has stimulated both world trade growth and FDI, and created new competitive pressures in many industries. Additionally, the overall number of multinational firms has grown dramatically as firms attempt to take advantage of market share, profit, and growth opportunities that are increasingly available in the global economy. The increase of firms in the emerging global market seeking new avenues for growth has generated enormous competitive pressure. This pressure has led multinationals to expand their quest for novel strategic opportunities in foreign markets, cultures, and nations, but it has also increased the risk of strategic failure, and ultimately, bankruptcy.

Entry into foreign marketplaces by an increasing number of multinational corporations has resulted in a corresponding upsurge in the amount of insolvency cases experienced in the international arena. This trend suggests that multination firms must become knowledgeable regarding transnational bankruptcy protocols. Previously, this investigation resided in the realm of legal scholars, but recent debates have centered this issue within the confines of multinational business strategy and its development (Brewerton and LeMaster, 2002).

\section{EMERGING ISSUES}

The advent of globalization has created two issues one of which is strategic and the other legal in nature: (1) the paramount obligation for a multinational company to coordinate a contingency strategy should its original strategy fails and an insolvency results; and (2) the obvious need for a uniform bankruptcy law and court system to manage international firm insolvencies. Although a firm typically does not consciously formulate a strategic 
objective to declare bankruptcy, without a contingency strategy in this area a multinational company could find itself preparing an insolvency plan without the guidance of prior strategic consideration. The reality of insolvency should be a fundamental component of any firm's strategic planning process. Acknowledgement of a potential insolvency should include an awareness of existing bankruptcy laws and courts, and the course of action necessary to minimize the negative impact of insolvency. The strategy literature provides only scant and general treatment of the formulation of insolvency contingency plans.

The community of legal scholars seems largely in agreement that the ideal adjudication of transnational insolvencies requires a standardized bankruptcy law and uniform court system that do not exist at this time. The lack of a single standardized system to manage insolvencies in the international arena has sparked dialogue within the community of legal scholars that focuses on the desire to obtain the optimal legal solution for resolving international defaults. Guzman (2000) suggests methods for the adjudication of international insolvencies that are polar extremes. The methods are the "territorialism" model and the "universalism" model. A brief summary of each model follows.

\section{THE TERRITORIAL MODEL OF BANKRUPTCY LAW}

Territoriality is a concept that each individual country holds the sovereign right to govern within its own borders. This perception is a basic tenant of international law that is simply accepted but also often overlooked. It is considered the default rule for many areas of law including constitutional law, taxation, trademarks, industrial regulation, debt collection and bankruptcy (LoPucki, 2000). Within the realm of multinational corporations and bankruptcy law, the application of territoriality or territorialism indicates that the designated bankruptcy court of a nation holds jurisdiction over those portions of the firm that strictly operate within its borders and excludes those portions that occur outside the national boundary (LoPucki, 2000). In lieu of binding treaties or other agreements to the contrary, nations operating under the territorial system are restricted to enforcing local laws on assets or persons within their own borders. Until the establishment and enforcement of such treaties or agreements, the prevailing system, territorialism, is the international law of bankruptcy.

In the case where a multinational corporation encounters financial problems that fall within the boundaries of a single nation, the firm has two options: liquidation or reorganization within that country while the firm's foreign entities remain unaffected. In the case where a firm's assets are solely confined to domestic operations in a single country, the options are liquidation or reorganization pursuant to the insolvency laws that govern the nation in which operations are based.

In the case where a firm's operations reach across national boundaries and financial difficulties arise, each individual entity follows the insolvency protocol that presides where the assets are held. The result is the creation of one bankruptcy estate in each country where assets are held. Under the territorial system, cooperation is a fundamental requirement among governing entities across borders. In essence a "parallel" bankruptcy proceeding commences in each individual country with a local court appointing a representative assigned to each estate for the duration of the insolvency proceeding. The court-appointed representative is charged with the duty to negotiate a court-approved remedy to resolve the financial issues with the knowledge that the actions may require cooperation that extends across national borders. When the estates are considered as a combined entity and found to hold greater value than their individual holdings, the court-appointed representatives should facilitate the proceeding to honor the consolidated amount. If the representatives are unable to reach an agreement regarding the assets in the consolidated amount, the assets are liquidated or reorganized with the proceeds distributed pursuant to each respective country's governing insolvency laws.

\section{THE UNIVERSALISM MODEL OF BANKRUPTCY LAW}

In absolute terms universalism stipulates that the administration of multinational insolvency cases be managed by a court that provides a single bankruptcy law applied within the debtor firm's home nation. Westbrook (2000) and Guzman (2000) both extol the benefits of universalism. Universalism is viewed as both a realistic tool 
and a simpler, more effective way to manage the complexities of multinational insolvency cases. However, universalism is predicated on several assumed conditions about the real world.

Westbrook (2000) stipulates that two essential components required under a universalism construct are the necessity for a single presiding bankruptcy law and a single forum (court and/or court system) to govern each multinational case. A single insolvency law that is recognized across national borders would provide a single set of protocols for the administration and dispersing of assets. A universal system would foster a sense of equality for all involved stakeholders due to the propagation of similar legal rights extended across the globe. The acceptance of a single governing law would provide a fluid framework for the transfer-avoidance rules that protect all creditors against strategic behavior by debtors and other creditors (Westbrook, 2000).

The establishment of a unified system of international bankruptcy courts would provide complementary benefits. A single bankruptcy court system that administers a single bankruptcy law should produce a more reliable and predictable set of bankruptcy case outcomes. If there were but a single international bankruptcy court (as contrasted to a unified court system), an even higher degree of uniformity, consistency, and predictability would likely be possible. A single court would provide a unified approach to assembly and sale of assets, could more effectively protect those assets prior to sale, and would make prevention or reversal of debtor fraud easier and more certain. This is a particularly urgent need in a world of electronic funds transfer, asset protection trusts, and other devices currently being used to accomplish debtor fraud.

A balance between the prevailing laws and the marketplace is also required under the universalism system. This system demands that the governing laws encapsulate all the related transactions and stakeholders in the market. In addition to the balance between the prevailing laws and the marketplace, the universalism model requires a convergence to occur among other laws that preside over creditors' priority, setoff, security interests, debt collection and other related concepts. The political function that surrounds all policy-making and negotiation is the apparent stalling mechanism responsible for failure to adopt the universal model. Consequently, according to Westbrook (2000) the universalism model is not likely to be adopted in the foreseeable future. The global market provides a bridge to the convergence of these related laws supported by the initiatives of the International Monetary Fund and the World Bank (Westbrook, 2000). Countries such as Germany, Argentina, Australia, Canada, Japan, Russia, China, and most of Eastern Europe have rewritten their insolvency laws, while Singapore, Indonesia, and Thailand have instituted insolvency laws, and Japan, Great Britain, and Mexico have reformed their prevailing laws. Additionally there has been a proliferation of the United Nations Model Law on Cross Border Insolvency presented by the United Nations Commission on International Trade Laws (UNCITRAL). The European Union and NAFTA nations' dedication to creating a clear coordination of transnational insolvency procedures is yet another example of the convergence of related laws. These adoptions, revisions, reforms, and initiatives are the result of an extensive examination and analysis of these nation's insolvency laws and reform proposals (Westbrook, 2000).

\section{BANKRUPTCY LAWS IN SELECTED ASIAN COUNTRIES}

The Asian countries selected for this study were Japan, South Korea, the People's Republic of China, and Taiwan. The criteria used to select the countries in this study included average annual percentage of gross domestic product growth (GDP), percentage growth in FDI, and membership in the World Trade Organization. These four countries were chosen due to their substantial growth across these indicators from 2000 to 2005 (www.worldbank.org, 2007), and because there seems to be a strong correlation between these factors and an observed propensity to modify bankruptcy laws to accommodate and stimulate growth in GDP and FDI.

\section{Japan}

Japan is still considered to be a very progressive, highly industrialized nation even though it has experienced severe economic distress as evidenced by the significant decrease in GDP over the last 20 years. FDI in Japan has also waned from a high of $\$ 12.3 \mathrm{~B}$ in 1999 to $\$ 8 \mathrm{~B}$ in 2004 (www.worldbank.org, 2007). The answer to Japan's economic distress may result from further infrastructure reforms to regain its competitive position. Although essential improvements have occurred in the telecommunications and financial services sectors, sustained 
recovery hinges on a renewed confidence that can only be achieved through "continued structural reforms" (WTO, 2007, p. 1), one of which may involve additional modification of insolvency laws.

Japan's current insolvency laws originate from several laws, including the Commercial Code Law No. 48, of 1899, Bankruptcy Law No. 48 of 1900, Company Reorganization Law No. 172 of 1952, and most recently the Civil Rehabilitation Law of 2000. Following multiple amendments, five legal systems exist that are organized into two categories: liquidation-type systems and reconstruction-type systems (Worldbank GILD, n.d.). The liquidation types include bankruptcy, hasan, governed by the Bankruptcy Law and special liquidation, tokubetsu-seisan that is governed by Commercial Code, both under Law No. 48. The grounds for filing for insolvency under the liquidation-type system are two-fold: 1) when the debtor is continuously unable to make his payments, and 2) when the sum of the assets is exceeded by the liabilities (Worldbank GILD, n.d. p. 5). When insolvency is adjudicated a trustee is appointed by the court.

The second category of reconstruction insolvencies is handled through reorganization, arrangement, and rehabilitation legal systems. Reorganization allows a firm to find a way out of its insolvency rather than liquidating. If the court agrees that rehabilitation is possible then with the agreement of both the creditors and the court, the debts are discounted and rescheduled. Reorganization in Japan has some similarities to Chapter 11 provisions of the U.S. Bankruptcy code. Company arrangements are much more flexible than reorganization and are designed to help a company resolve its insolvency issues without liquidating. Company arrangements appear to be exactly what the term suggests: an arrangement between debtors and creditors that allows the company to continue operations without liquidating. One major difference between company reorganization and arrangement is that the management of the firm does "not necessarily lose control of the company" under a corporate arrangement (Worldbank GILD, n.d., p. 2).

A civil rehabilitation of a firm is similar to company arrangement only from the perspective of management not losing control of the firm. The purpose of management maintaining control in this case is to "administer and dispose of the properties" (Worldbank GILD, n.d., p. 2), while there are other "rules" that prevail regarding security interests. What is an extraordinary rule is that the debtor can elect on his/her own initiative to extinguish the security interests required for continuance of the business. These security interests include real property and personal property. In all cases the most commonly used form for resolution of insolvency issues is through "private arrangements" rather than formal legal proceedings (Worldbank GILD, n.d., p. 1).

\section{South Korea}

South Korea, like Japan, became a member of the World Trade Organization in 1995. From 2000 to 2004, South Korea has outpaced Japan both in terms of the annual percentage of gross domestic product and FDI, excluding FDI net inflows of 2003 (www.worldbank.org, 2007). Given that Japan is at least twice the size of South Korea, economically, these differences are understandable. However, GDP growth for South Korea is projected to increase only slowly over the next couple of years (www.economist.com, 2005). The slowdown is attributed to the anticipated decrease in exports.

Both composition and corporate reorganization are used in South Korea to resolve insolvency problems (Worldbank GILD, n.d.). Composition allows for the firm to continue to operate, and protects secured claims from being impeded. Corporate reorganization is designed only for corporations. It requires that a trustee be assigned by the courts to administer the reorganization. All entities, even secured claims, are subject to the restrictions imposed by corporate reorganization. Unlike composition, corporate reorganization can be initiated by either the debtor(s) or the shareholder(s).

Among the four countries studied, South Korea's insolvency laws most closely emulate the territorialism model of bankruptcy. Currently, what happens in South Korea stays in South Korea, because there is no recognition of foreign bankruptcy proceedings. Consequently ancillary administration of insolvency proceedings is not possible. If the debtor firm is situated inside South Korea, but insolvency proceedings are initiated outside of the nation, the proceedings are simply not recognized. Also, if insolvency proceedings are begun domestically there is no standing 
regarding assets held outside the country (Chung, 2005; Han, 2005). The only possible exception is with respect to cross-border insolvency that is addressed in a separate section.

South Korea has pending legislation regarding insolvency that proposes a rehabilitative procedure. This procedure will create a debtor-friendly scenario providing for the possible continuation of management by the firm managers. Proposed in 2003, this legislation is entitled the Act on Rehabilitation and Bankruptcy of Debtors, but is also known as the Unified Insolvency Act (Chung, 2005; Han, 2005). The Act requires the appointment of a company representative for the debtor firm, while the court may impede debt collection until the reorganization procedures begin (Han, 2005).

\section{People's Republic Of China}

Over the past few years the People's Republic of China (PRC) has demonstrated extraordinary average annual percentage GDP growth and FDI inflows compared to other Asian countries. The PRC became a member of the World Trade Organization in 2001 and experienced an average annual percentage GDP growth of $8 \%$ in 2000 and 10\% from 2003 to 2005, with FDI increasing from \$38.8B in 1999 to $\$ 55.5 \mathrm{~B}$ in 2005 (www.worldbank.org, 2007). Not surprisingly the PRC does not have a unified bankruptcy law (Barker and Purser, 2004), nor do the PRC law provisions closely approximate the type of bankruptcy law provisions found in the most economically developed countries. Bankruptcy procedure is dependent upon the type of entity claiming insolvency and among other governmental and regulatory bodies, the approval of the Ministry of Commerce. The courts have very limited involvement, if any, given that a separate independent judiciary with bankruptcy expertise does not exist. Similarly, the reallocation of assets occurs before the remainder is paid out to the creditors. The creditors have little recourse if they disagree with the outcomes and have minimal opportunity to participate in the bankruptcy process. As a consequence the "reallocation" or disposition of assets may not result in maximizing recoveries and the creditors are left with less than what possibly could have been recovered (Barker and Purser, 2004).

The PRC is a phenomenal case due to the intense multinational interest in doing business in or with China as evidenced by the enormous FDI inflows. Given this enormous economic growth in the PRC and the accompanying unknowns for foreign entities operating there, it seems that both the PRC as well as the strategists employed by the companies going to China should be immensely interested in the laws and resolutions regarding insolvency. Currently, the legal infrastructure in the PRC is improving its inefficient and ill-defined insolvency practices (Kwan, 2006; Field, 2005).

The PRC Enterprise Bankruptcy and Reorganization Law, also known as the Draft Bankruptcy Law (DBL), was introduced in June 2004 as a means toward the reform of outdated and inadequate existing laws. Wang (2005) explained that the DBL will make "bankruptcy a more viable means of debt liquidation", but the problem is that beyond the inability to pay overdue debts there is no explanation required regarding the reasons for the firm filing bankruptcy (p. 5). With anticipation of reforming previous outdated and narrow laws governing bankruptcy, Jing (2004) reported that the new bankruptcy law will address reciprocity in an effort to move legal processes away from the former territorialism model toward a limited universalism model. This discussion incited debate and eventually evolved into a further reaching law.

The Corporate Bankruptcy Law will go into effect June 1, 2007. This law provides stipulations regarding "the procedure for a company's bankruptcy and liquidation" and discusses the rights of involved parties (Kwan, 2006, p. 1). Previously, State-owned Enterprises (SOEs) in the PRC were provided government subsidy during a bankruptcy process (Kwan, 2006; Luan, 2006; New Bankruptcy Law, 2006). Until the new Law is enacted, SOEs will receive governmental support. The new Law is a move toward international agreements by holding "debtor's overseas assets" and acknowledging foreign judicial findings regarding insolvency cases (Kwan, 2006, p. 1).

\section{Republic Of China (Taiwan)}

Taiwan has experienced terrific economic growth reporting an average annual percentage GDP growth of $3.1 \%$ from 2001 to 2005 and $4.3 \%$ in 2006 (www.economist.com, 2007). A leveling off is expected as part of the normal process of growth and development. Among the four countries of study, Taiwan is the newest member of the World Trade Organization joining in 2002. The need for insolvency reform is a result of the positive economic 
growth, but to date no unified code for bankruptcy exists. Insolvency disputes in Taiwan do not involve lawsuits or legal disputes. They are considered "non-litigious" procedures (Lui, Lee, and Li, 2002).

Insolvency proceedings are governed by different entities in Taiwan (Lui et al., 2002). For example corporate reorganization for publicly-held companies is governed by The Company Law that is maintained by the Ministry of Economic Affairs. Subsidiaries, however, are not included. Liquidation and composition proceedings are governed by The Bankruptcy Code that is maintained by the Judicial Yuan, but there is no bankruptcy court.

Insolvency law reforms in Taiwan began in the 1990's and since that time the Company Law and the Bankruptcy Law were amended with the suggestion that the UNCITRAL Model Law on Cross-Border Insolvency be employed as a guide for reform (Lui et al., 2002). There is no evidence that reformation efforts to create a unified law to resolve bankruptcy have resulted in substantial changes. A white paper on banking in Taiwan noted that no real progress had been made and the recommendation for legislative reform was reiterated (American Chamber of Commerce, 2004). An outstanding example of the need for reform and the evidence of no real progress having been made is a company, Tanun, that filed for reorganization and after 16 years still does not have a plan for reorganization (McGowan, 2001). It appears that the call for reform has gone unheard and Taiwan's Reorganization Law remains grossly inefficient and biased (American Chamber of Commerce, 2006).

\section{CROSS-BORDER INSOLVENCY}

Given globalization, internationalization, and the continued growth in multinational corporations, the need for laws governing cross-border insolvency should be paramount to countries and corporations. In 1997, the UNCITRAL Model Law on Cross-Border Insolvency was adopted by the United Nations General Assembly. The Model Law was "designed to assist States to equip their insolvency laws with a modern, harmonized, and fair framework to address more effectively instances of cross-border insolvency" (UNCITRAL, 1997, p. 15). Insolvency is defined as "when a debtor is generally unable to pay its debts as they mature or when its liabilities exceed the value of its assets" (UNCITRAL Legislative Guide on Insolvency Law, 2005, p. 5). Cross-border insolvency is defined as "an insolvency case that has been commenced in one jurisdiction but which is relevant to another or other jurisdiction" (Harmer and Fisher, 2002, p.2). Cross-border cases concern those cases initiated in one location by the appropriate creditor, shareholder, or debtor, but the assets or other creditors or concerned entities reside in another location, each with different jurisdictions.

The General Assembly's resolution included provisions for (1) transmitting the text of the law along with a guide to its enactment to governments and interested bodies; (2) recommending that member states review their cross-border insolvency legislation to determine its compatibility with the Model Law and to give favorable consideration to the Model Law; and (3) recommending that the Model Law become "generally known and available." (United Nations A/Rec/52/158). The adoption of the UNCITRAL Model Law represents a major development toward the eventual achievement of a single universal law governing multinational insolvencies. However, the United Nations has no policing authority that might mandate the adoption of the Model Law as the insolvency law of the land. Individual states are free to ignore or embrace the Model Law - wholly or partially - as they see fit.

In the absence of laws or legal venues that govern cross-border insolvencies, informal processes take over that may not ensure fairness of resolutions of insolvencies. Some countries follow "common law" where the principle of "comity" exists. Comity is a judge-made doctrine, unsupported by legislation, but is designed to assist in resolutions between or among different jurisdictions (Harmer and Fisher, 2002). The advantage of comity is that in the absence of treaties or conventions, or other types of agreements, a court can employ comity to help settle a case. The disadvantage is the lack of consistency of application of the use of comity and the uncertain and unpredictable results it produces. 


\section{EARLY IMPACT OF THE MODEL LAW}

In 2001, Japan enacted the Law on Recognition of and Assistance in Foreign Insolvency Proceedings. This law was designed after the UNCITRAL Model Law on Cross-Border Insolvency (Field, 2005). Prior to this time Japan practiced territorialism with regard to cross-border asset disagreements and bankruptcies (Takagi, 2004). Under the new law after the debtor's trustee has filed for the bankruptcy, the foreign representative must prove the residence/office of the debtor is located within the country where the Foreign Proceeding was filed. In essence, an appointed trustee is given the right to apply for recognition in court for a foreign bankruptcy case (Takagi, 2004).

In South Korea, the territorial model of bankruptcy applies, except with the Corporation Reorganization Act of Korea that provides aliens of foreign corporations can hold the same status as that of a Korean national (Park, 2003). The intent of the proposed Act Concerning the Rehabilitation and Bankruptcy of Debtors is to unify prevailing insolvency statutes and abandon the territorial model (Han, 2005). It appears that the PRC is moving away from the territorial model that did not acknowledge foreign judicial findings and has managed domestic insolvency cases on an individual basis. The PRC's new Corporate Bankruptcy Law is a step toward the crossborder model with its recognition of foreign court's findings and grasp on foreign assets held by a debtor. Crossborder issues seldom arise in Taiwan primarily, because foreign investors create subsidiaries within Taiwan and Taiwanese investors establish subsidiaries outside Taiwan. As a consequence, territorialism with regard to whichever country holds the assets prevails in Taiwan. Taiwan's insolvency laws apply only to local legal proceedings.

\section{CONCLUSIONS}

This paper has presented the current status of four Asian nations' insolvency laws in light of the current globalization phenomena. These firms were selected for this study based on their recent growth in GDP and FDI, and their membership in the world Trade Organization. This comparative analysis should assist multinational companies in formulating contingency plans while operating in the international arena by providing current information regarding the manner in which multinational insolvencies are resolved. The survey of insolvency laws produced a number of conclusions.

The first conclusion of this paper is that the recent developments and changes in bankruptcy laws in the four study countries provide scant evidence that the countries' laws are moving the countries in the direction of universalism despite such claims by other authors and researchers. The recent changes in Japan's laws include provisions which parallel to some extent the provisions contained in many of the western countries' laws, but fall far short of approaching any type of universal statute. South Korea's bankruptcy statute clearly remains strictly territorial in nature and completely disdains all proceedings of foreign countries. The Peoples Republic of China has made recent changes in bankruptcy law provisions that bear some similarity to the provisions commonly found in western countries' bankruptcy statutes but taken as a whole the PRC statutes still must be viewed as extremely territorial in nature and generally unlike the statutes found in any of the developed countries. Similarly, so-called reforms in the prevailing laws in Taiwan that bring the country closer to emulating western countries' laws are more rhetorical than substantive, and Taiwan's laws continue to be a prime example of extreme territorialism.

A second conclusion of this paper is that the UNCITRAL Model Law on Insolvency has some impact, thereby influencing some countries' efforts to reform their bankruptcy laws to include general provisions found in most western countries' laws. There is some evidence of the influence of the UNICITRAL law on the development of new bankruptcy law provisions in both Japan and the People's Republic of China, but the influence seems minimal at this time. The UNICITRAL Model Law seems to be the major factor currently affecting bankruptcy law reform efforts in a number of countries. However, the nature of the reforms as manifested in changes to bankruptcy statutes in various countries cannot be described as a global movement toward universalism. At best, the recent changes in bankruptcy statutes in these countries can be characterized as a movement toward "limited universalism" or "modified territorialism." Regardless of which term is used, the developments have not been sufficiently significant to signal a major movement toward a single global bankruptcy law applicable to all countries, nor do these developments suggest that there is a movement toward a single court system for adjudicating multinational insolvencies. 
A final conclusion of this paper is that the recent changes in bankruptcy laws in the four study countries provide little guidance to multinational company strategists. The answer to the question, "Should multinational company strategies be concerned?" is "yes", but with qualifications.

On the positive side, strategists should applaud the changes in the four countries' bankruptcy laws, because they collectively suggest that the provisions of the four countries' laws are becoming more similar to provisions typically found in western countries' laws. On the negative side, the four countries' bankruptcy adjudication systems remain distinctive and different, are clearly territorial in nature, and will continue to require intense study to determine the optimal strategic actions to be followed in the event that an insolvency occurs within any of these countries.

\section{REFERENCES}

1. American Chamber of Commerce (2004). Taiwan White Paper. http://www.amcham.com.tw/dl/2004WP_Positions.pdf.

2. American Chamber of Commerce (2006). Taiwan White Paper. http://www.amcham.com.tw/d1/2006wp.pdf.

3. Barker, M. and Purser, R. (2004). Bankruptcy reform in China, Freshfields, Bruckhaus, and Deringer. www.globalinsolvency.com.

4. Brewerton, F.J., and LeMaster, J. (2002). Emerging models of international bankruptcy law: Strategic implications for multinational companies. International Business and Economics Research Journal (1) 10: 1-9.

5. Chung, K.S. (2005). Korean government's proposed bill for the unified insolvency act. http://adb.bdw.com.uia.

6. Economist (2005). Economist Forecast. http://www.economist.com/countries/SouthKorea.

7. Economist (2007). Economist Factsheet. http://www.economist.com/countries/Taiwan.

8. Field, A.M. (2005). New global rules for bankruptcy. The Journal of Commerce.

9. Guzman, A.T. (2000). International bankruptcy: In defense of universalism. Michigan Law Review (98): 7: 21772215.

10. Han, S. (2005). New unified insolvency act. www.asialaw.com.

11. Harmer, R. and Fisher, R. (2002). Promoting regional cooperation in the development of insolvency reform. Asian Development Bank. http://adb.bdw.com.

12. Hill, C.W.L. (2001). Global Business. Boston: Irwin McGraw-Hill.

13. Jing, Z. (2004). China's new bankruptcy law perfect the legal system of the market economy. China Economic Net. http://en-1.ce.cn.

14. Kwan, C.H. (2006). Putting in place the legal framework for a market economy. China in Transition. http://www.rieti.go.jp/en/china.

15. LoPucki, L.M. (2000).The case for cooperative territoriality in international bankruptcy. Michigan Law Review (98): 7, 2216-2251.

16. Luan, S. (2006). China's top legislature adopts corporate bankruptcy law. www.chinaview.cn.

17. Lui, Lee, and $\mathrm{Li}$ (2002). Border insolvency and informal workouts: A look at chinese taipei. http://www.oecd.org.

18. McGowan, T. (2001). Special focus on banking: A call for reform. American Chamber of Commerce. http://www.amcham.com.tw.

19. New Bankruptcy Law (2006). International Financial Law Review (24): 6, 94. http://www.iflr.com.

20. Park, J. (2003). Country Report for the Republic of Korea. World Bank Global Insolvency Law Database.

21. Takagi, S. (2004). Cross-border insolvency in Japan, International Business Lawyer, 15-17.

22. UNCITRAL (1997). UNCITRAL Model Law on Cross-border Insolvency. http://www.uncitral.org/english/texts/insolven/insolvency.htm.

23. UNCITRAL Legislative Guide on Insolvency Law (2005). http://www.uncitral.org/pdf/english/texts/insolven/0580722_Ebook.pdf.

24. Wang, F. (2005). An overview of the draft enterprise bankruptcy law of the People's Republic of China, China Law Developments. www.kingandwood.com.

25. Westbrook, J.L. (2000). A global solution to multinational default. Michigan Law Review (98): 7, 2276-2328.

26. Worldbank org (2007). http://web.worldbank.org/WBSITE/EXTERNAL/DATASTATISTICS.

27. Worldbank GILD (n.d.). Japan: Insolvency overview. http://www.web.worldbank.org.

28. WTO (2007). Trade Policy Review: Japan. http://docsonline.wto.org. 